\title{
EU AND WTO REGULATORY APPROACHES TO RENEWABLE ENERGY SUBSIDIES: NEGATIVE AND POSITIVE INTEGRATION
}

\author{
Ilaria Espa*and Gracia Marín Durán
}

\begin{abstract}
This paper compares how the EU and the WTO have grappled with balancing the negative (trade-distortive) and positive (climate change-mitigation) effects of renewable energy $(\mathrm{RE})$ subsidies. It first shows that, although both subsidy control regimes share some basic tenets of negative integration (i.e. prohibiting tradedistortive RE subsidies), EU State aid law is comparatively more constraining on governments' space to support green energy in both substantive and procedural/institutional terms. It then argues that the more negative integration is strictly framed and implemented, the greater the need for positive integration (i.e., sheltering trade-distortive but climate-friendly $R E$ subsidies under certain conditions). This, in turn, goes a long way in explaining why the EU's regulatory model is also distinct for having progressively established a set of common rules on permissible "good" RE subsidies. With this in mind, the paper assesses the extent to which the absence of a comparable positive integration dimension in the WTO legal framework exposes RE subsidies to the risk of WTO-illegality. It finally argues that while comparing the two regimes may be useful from a theoretical standpoint, a transposition of the EU's positive integration approach to the WTO is not desirable for a variety of legal, political and institutional reasons.
\end{abstract}

\section{Introduction}

It goes largely undisputed that climate change is possibly the greatest sustainable development challenge presently facing the international community, and the 1992

\footnotetext{
Ilaria Espa is an Assistant Professor, Università della Svizzera Italiana (Lugano, Switzerland) and Senior Research Fellow, World Trade Institute (Bern, Switzerland). *Gracia Marín Durán is an Associate Professor in International Economic Law, University College London (London, United Kingdom). We are very grateful to Rike Krämer and all the participants in the workshop on "EU and WTO Approaches towards Trade and Environment" (Ruhr Universität, Bochum on 9-10 May 2016) for the rich exchanges on the topic. All opinions and any errors remain our own. This Article partially draws on Espa I and Marín Durán G (2018), Espa (2017a), and Marín Durán G (2018).
} 
United Nations Framework Convention on Climate Change (UNFCCC) and more recent 2015 Paris Agreement represent the global response to this challenge with the ultimate objective of reducing greenhouse gas (GHG) emissions concentrations in the atmosphere and "holding the increase in the global average temperature to well below $2^{\circ} \mathrm{C}$ above pre-industrial levels". ${ }^{1}$ Similarly, there is broad consensus that replacing conventional "brown" or "dirty" energy (i.e. generated from fossil fuels such as coal, natural gas and oil) with renewable "green" or "clean" energy (i.e. generated from naturally replenished resources such as solar or wind) can play an important role in mitigating climate change and achieving the internationally agreed $2^{\circ} \mathrm{C}$ target. $^{2}$ But while the need for government intervention to boost renewable energy (RE) is generally accepted, ${ }^{3}$ which specific forms of public support are most appropriate or effective towards combating climate change remains a contentious issue. In other words, what 'policy space' should governments have in supporting the transition to a low-carbon green economy? And indeed, how to strike a proper balance between the negative (trade-distortive) and positive (climate change-mitigating) effects of green energy subsidies?

The aim of this article is to compare how the EU and the WTO have grappled with these complex and highly contested questions, through the lens of negative and positive integration. In doing so, it will focus on the power sector since it has been the largest single source of GHG emissions, on the one hand, and the primary target of

\footnotetext{
1 United Nations Framework Convention on Climate Change (UNFCC), signed on 9 May 1992, 771 U.N.T.S. 107, Article 2; Paris Agreement, signed on 12 December 2015, Article 2(1)(a), further providing "[...] and pursuing efforts to limit the temperature increase to $1.5^{\circ} \mathrm{C}$ above pre-industrial levels".

2 Paris Agreement, ibid., Articles 3 and 4(2); International Renewable Energy Agency (IRENA) Rethinking Energy 2017: Accelerating the Global Energy Transformation (2017), https://www.irena.org/documentdownloads/publications/irena rethinking energy 2017.pdf (last accessed 6 February 2018), pp. 23-24. This is because the energy sector is still contributing to more than two thirds of global GHG emissions: see International Energy Agency (IEA) Energy, Climate Change and the Environment: 2016 Insights (2016), https://www.iea.org/publications/freepublications/publication/ECCE2016.pdf (last accessed 6 February 2018), p. 17.

3 The case for government intervention is made on the basis of both the climate-related benefits (or positive externalities) of green energy and the climate-related costs (or negative externalities) of conventional energy: see, inter alia, Marín Durán (2018), pp. 133-134. According to latest estimates, renewable energy subsidies rose to USD 140 billion in 2016, although this is still lower than fossil-fuel subsidies which amounted to USD 260 billion in that same year. IEA Commentary: Fossil-fuel Consumption Subsidies Are Down, But Not Out (20 December 2017), https://www.iea.org/newsroom/news/2017/december/commentary-fossil-fuel-consumption-subsidiesare-downbut-not-out.html (last accessed 6 February 2018).
} 
public incentives to renewable energy, on the other hand. ${ }^{4}$ Based on latest statistics, in 2015, 110 countries implemented some form of government support in the electricity sector compared to 66 and 21 countries in the transport sector and in the heating and cooling sector, respectively. ${ }^{5}$ The single most common form of public support to green electricity generation have been feed-in tariff (FIT) schemes offering long-term guaranteed prices for renewably generated electricity (particularly using solar photovoltaic (PV) and wind technologies) fed into the grid. ${ }^{6}$ FITs have not only been a popular choice, but also widely recognized as the "most efficient and effective" policy instrument for promoting green electricity by the Intergovernmental Panel on Climate Change and other international expert bodies. ${ }^{7}$ Another common form of government support in the electricity sector are fiscal measures (e.g. tax exemptions/reductions) and public finance (e.g. grants and preferential loans) to encourage investment in and deployment of renewable energy technologies, ${ }^{8}$ and these have been projected to increase substantially in the International Energy Agency's "Bridge Scenario" from $\$ 270$ billion in 2014 to $\$ 400$ billion in 2030 . $^{9}$

The comparative analysis begins by exposing how EU State aid law and WTO subsidy law are similar in their approach to negative integration, understood as the set of substantive disciplines and institutional mechanisms aimed at prohibiting or limiting the use of government support measures that are trade-distortive and hence deemed harmful from an EU/international trade perspective. It will be shown that whilst both

\footnotetext{
${ }^{4}$ In 2015, the electricity sector still accounted for approximately 40 per cent of global energy-related GHG emissions due to the heavy reliance on fossil fuels.: IEA (2017), CO2 Emissions from Fuel Combustion: Highlights, https://www.epa.gov/ghgemissions/global-greenhouse-gas-emissions-data (last accessed 6 February 2018), p. 13.

${ }^{5}$ Renewable Energy Policy Network for the 21st Century (REN21) Renewable 2016 Global Status Report (2016), http://www.ren21.net/wp-content/uploads/2016/06/GSR 2016 Full Report.pdf (last accessed 6 February 2018), p. 112.

${ }^{6}$ A detailed examination of countries' policy practice is beyond the scope of this Article, see inter alia: Espa and Marín Durán (2018), pp. 623-628 and references therein.

7 Intergovernmental Panel on Climate Change (IPCC) Renewable Energy Sources and Climate Change Mitigation - Summary for Policy Makers and Technical Summary (2012), https://www.ipcc.ch/pdf/special-reports/srren/SRREN FD SPM final.pdf (last accessed 2 September 2017), p. 152, outlining the main elements of 'well-designed' FIT programmes; see also Charnovitz and Fischer (2015), p. 184, referring to estimates that FITs are responsible for about $75 \%$ of global solar $\mathrm{PV}$ and $45 \%$ of global wind capacity.

8 For an overview, REN21 (2013), Renewables 2013 - Global Status Report, http://www.ren21.net/Portals/0/documents/Resources/GSR/2013/GSR2013 lowres.pdf (last accessed 6 February 2018), pp. 68-70; and REN21 (2016), Renewables 2016 - Global Status Report, http://www.ren21.net/wp-content/uploads/2016/05/GSR 2016 Full Report lowres.pdf (last accessed 6 February 2018), p. 8.

9 IEA (2015), Energy and Climate Change - World Energy Outlook Special Report, https://www.iea.org/publications/freepublications/publication/WEO2015SpecialReportonEnergyandCli mateChange.pdf (last accessed 6 February 2018), pp. 13 and 85.
} 
regulatory systems follow this logic of negative integration, they are fundamentally different in important respects. Overall, EU substantive disciplines and control mechanisms are comparatively stronger in constraining government support, which is a direct reflection of the more ambitious objectives of EU State aid law (Section 2). This, in turn, goes a long way in explaining why the EU's regulatory model is also distinct for its positive integration dimension: that is, the progressive establishment of common substantive and procedural rules for permitting, under certain conditions, State aid to renewable energy, using a combination of both hard-law and soft-law instruments (Section 3). It will be then assessed whether the absence of a comparable system for justifying green energy subsidies under WTO law is actually problematic: in other words, are these measures genuinely at risk under current WTO subsidy rules, and thus in need of a legal shelter? (Section 4). The final section of the paper explores which lessons, if any, may be drawn for the WTO from the EU regulatory experience in terms of positive integration. In this regard, it will be argued that it is hardly conceivable, or even desirable, that the EU's approach to sheltering renewable energy government support could be transposed to the WTO for a variety of legal, political and institutional reasons (Section 5).

\section{A Common but Different Approach to Negative Integration}

In a basic sense, both EU State aid law and WTO subsidy law follow the logic of negative integration in that they seek to constrain trade-distortive governmental support. In the former regulatory system, the key provision to this effect is Article 107(1) of the of the Treaty on the Functioning of the European Union (TFEU), which lays down a general prohibition on "any aid granted by a Member State or through State resources in any form whatsoever which distorts or threatens to distort competition by favouring certain undertakings or the production of certain goods ... in so far as it affects trade between Member States". ${ }^{10}$ According to the case law of the EU Court of Justice (CJEU), four cumulative conditions have to be met for a government measure to fall under this prohibition: (i) it must confer an economic advantage on the recipient that it would not have received under normal market

\footnotetext{
10 The present contribution focuses exclusively on the treatment of RE subsidies under EU State aid law. For a discussion in relation to EU internal market law (particularly Articles 34 and 36 TFEU), including recent case law, see $\mathrm{E}$. Reid's contribution to this special issue.
} 
conditions; (ii) it must entail an actual or potential use of State resources; (iii) it must be selective, by favouring certain undertakings or the production of certain goods; (iv) it must be liable to distort competition and affect intra-EU trade. ${ }^{11}$ In principle, this general prohibition equally applies to renewable energy support schemes, since the purpose of State aid is irrelevant under Article 107(1) TFEU.

At first glance, some degree of similarity may be readily noticed between Article 107(1) TFEU and the three cumulative conditions for a given measure to constitute a "subsidy" under the WTO Agreement on Subsidies and Countervailing Measures (ASCM): (i) it must be a financial contribution (or income/price support) by a government or public body ${ }^{12}$ (or by a private body "entrusted" or "directed" by a government) ${ }^{13}$ (ii) it must confer a benefit (i.e., analogous to "economic advantage" under EU State aid law); ${ }^{14}$ (iii) it must be specific (i.e., analogous to the "selectivity" condition under EU State aid law). ${ }^{15}$ But as will be shown next, the scope and depth of negative integration in these two regulatory regimes fundamentally differs in both substantive and procedural terms, with the overall result that WTO subsidy disciplines are less constraining on green policy space. ${ }^{16}$

The first significant difference relates to the threshold requirement of "benefit" for a government support measure to be subject to ASCM disciplines, and the parallel "economic advantage" condition under EU State aid law. In both systems, the existence of a benefit or economic advantage needs to be determined in relation to prevailing conditions in the marketplace, which raises the question as to what

\footnotetext{
11 See further Bacon (2013), pp. 20-87.

12 Articles 1.1(a)(1)(i)-(iii) and 1.1(a)(2) ASCM.

${ }^{13}$ Article 1.1(a)(1)(iv) ASCM.

14 Article 1.1(b) ASCM.

15 Articles 1.2 and 2 ASCM. As this does not differ fundamentally from the notion of 'selectivity' under EU State aid law, it will not be further discussed here: for a comparison, see Ehlermann and Goyette (2006), pp. 701-704.

${ }^{16}$ Admittedly, there is one exception to this general proposition in that the notion of "subsidy" under WTO law may in some respects be broader than that of "State aid" under EU law. This is because only measures that are both imputable to a Member State and financed directly or indirectly through "State resources" may be regarded as State aid under EU law. On this "cost to government" (or "charge on the public account") requirement, see in particular: Case C-379/98 PreussenElektra [2001] ECR I-2099, paras 58-62 and discussion in Carmona (2016), pp 222-224. By contrast, no similar "cost to government" requirement exists under WTO subsidy law: WTO Appellate Body Report, Canada Measures Affecting the Export of Civilian Aircraft, WT/DS70/AB/R, adopted 19 November 1999, para. 154 , rejecting Canada's argument that "cost to government" is one way of conceiving the existence of a "benefit" under Article 1.1(b) SCM Agreement. On this point, see further Marín Durán (2018), p. 141.
} 
constitutes the "relevant market". ${ }^{17}$ In the context of EU State aid law, market definition focuses on demand-side substitutability: that is, whether the products at issue are regarded as substitutes or reasonably interchangeable to meet the same consumer need. ${ }^{18}$ Applying this approach to FIT programmes, for instance, would lead to defining the relevant market in broad terms, as encompassing all electricity irrespective of its green or less green origin, ${ }^{19}$ and thereby pave the way for the conclusion that (administratively-set) feed-in tariffs grant an "economic advantage" to renewable electricity generators. ${ }^{20}$ Conversely, the definition of relevant market for the benefit comparison under the ASCM has become a more complex matter following the Appellate Body's report in Canada - Renewable Energy (2013). The approach followed here gave prominence, albeit controversially, ${ }^{21}$ to supply-side substitutability: otherwise said, the Appellate Body considered that the source of electricity, either conventional or renewable (in the case at issue, wind and solar), is determinative for the definition of the relevant market insofar as "windpower and solar PV producers of electricity cannot compete with other electricity producers because of differences in cost structures and operating costs and characteristics". ${ }^{22}$ Thus, the market for green electricity had to be distinguished from the wholesale electricity market, even though renewably-produced and conventional electricity were found to be highly substitutable on the demand-side. ${ }^{23}$ In addition, the Appellate Body found, again controversially, that markets for renewably-produced electricity can still provide appropriate benefit

\footnotetext{
17 WTO Appellate Body Report, Canada - Measures Affecting the Export of Civilian Aircraft, WT/DS70/AB/R, adopted 19 November 1999, para. 157 and Article 14(b)-(d) ASCM; Ehlermann and Goyette (2006), pp. 700-701.

${ }^{18}$ European Commission Notice on the Definition of Relevant Market for the Purposes of Community Competition Law' (97/C372 /03), OJ [1997] C372/5, para. 1, footnote 1, noting that "[t]he focus of assessment in State aid cases is the aid recipient and the industry/sector concerned rather than identification of the competitive constraints faced by the aid recipient." This distinguishes State aid cases from competition cases in EU law, as in the latter both demand-side and supply-side substitutability may be considered: see further, Rubini (2015), pp. 219-220.

19 Factors suggesting a high demand-side substitutability between renewable and conventional electricity is that all electricity is physically identical and performs the same end-use regardless of how it is generated: on this point see, WTO Appellate Body Report, Canada - Certain Measures affecting the Renewable Energy Generation Sector/Measures relating to the Feed-in Tariff Program, WT/DS412/DS426/AB/R, adopted 24 May 2013 [hereinafter Appellate Body Report, Canada Renewable Energy (2013)], para. 5.170; and further discussion in Charnovitz and Fischer (2015), pp. 201-202.

${ }^{20}$ See e.g., in relation to feed-in tariffs under the German EEG Act, European Commission State aid SA.38632 (2014/N) - Germany. EEG 2014 - Reform of the Renewable Energy Law (C(2014) 5081 final), 23 July 2014, paras. 121 and 149.

${ }^{21}$ A reference to the main academic critiques is given in Espa and Marín Durán (2018), pp. 634-635.

${ }^{22}$ Appellate Body Report, Canada - Renewable Energy/FIT Program (2013), para. 5.174.

${ }^{23}$ Appellate Body Report, Canada - Renewable Energy/FIT Program (2013), para. 5.178.
} 
benchmarks even when they are created by means of government intervention. ${ }^{24}$ By narrowing the definition of the relevant market to the "competitive markets for windand solar PV-generated electricity", ${ }^{25}$ rather than the wholesale electricity market as a whole, the Appellate Body has arguably made it harder to demonstrate the existence of a benefit and thereby created a partial carve-out for FIT programmes from ASCM disciplines. Even so, and importantly, the Appellate Body did not provide a full "safe heaven" to FIT schemes inasmuch as it pointed to ways in which complainants may establish the existence of a benefit in future cases (i.e., by looking at in-country price benchmarks, or adjusted out-of-country price benchmarks; or proxy construction). ${ }^{26}$ Nonetheless, when compared to EU State aid law, this jurisprudential approach grants greater flexibility to WTO members when supporting green electricity through FIT schemes. ${ }^{27}$

A second, and arguably more important, distinction between the two regulatory regimes concerns the adverse effects that government support must have in order to be sanctioned as incompatible with either EU State aid rules or WTO subsidy law. Here, the threshold under EU law is seemingly low: to be prohibited, selective State aid needs only to "be liable" to affect competition and intra-EU trade, and there is no requirement that this potential effect be significant or substantial. ${ }^{28}$ In other words, any State measure that provides selective aid through public resources is, in principle, deemed incompatible with the EU internal market, with no need to prove an actual distortive effect on competition or intra-EU trade. ${ }^{29}$ Conversely, under WTO law, tradedistortive effects are not generally presumed but only in two specific cases: namely, export subsidies (i.e., those contingent upon export performance) and importsubstitution subsidies (i.e., those contingent upon the use of domestic over imported goods). These are both expressly aimed at distorting trade and investment flows, and

\footnotetext{
${ }^{24}$ Appellate Body Report, Canada - Renewable Energy/FIT Program (2013), para. 5.175-85.

${ }^{25}$ Appellate Body Report, Canada - Renewable Energy/FIT Program (2013), para. 5.190.

${ }^{26}$ Appellate Body Report, Canada - Renewable Energy/FIT Program (2013), paras. 5.228 and 5.233. See further, Rubini pp. 218-220.

${ }^{27}$ Note that the Appellate Body's approach to the benefit analysis in Canada - Renewable Energy (2013) concerned the legal standard in Article 14(d) SCM and hence is applicable to FIT programmes as a "purchase of goods" by the government, but not to other forms of public support listed in Article 1.1(a) SCM (e.g., tax exemptions, grants or preferential loans). For further discussion, see Espa and Marín Durán (2018), pp. 633 and 639.

28 On this point see Flett, Jessen and Talaber-Ritz (2008), pp. 447-449.

${ }^{29}$ See further, Bacon (2013), pp. 12-13 and 82-87.
} 
thus prohibited outright. ${ }^{30}$ All other specific subsidies are just actionable under the ASCM, which means they are only WTO-incompatible to the extent it is demonstrated that they cause actual adverse effects to the import-competing (in the form of "material injury") ${ }^{31}$ or export-competing interests (in the form of 'serious prejudice') ${ }^{32}$ of another WTO member.

Because of this trade-injury focus of the ASCM, RE subsidies are thus not prohibited as such unless they incorporate a discriminatory component in the form of local content requirements (LCRs), but the latter are primarily tools of industrial policy with no clear environmental benefits. ${ }^{33}$ Among those non-discriminatory RE support schemes that are instead actionable under the ASCM, FIT schemes targeting green electricity face a lower risk of WTO-incompatibility than other public incentives given to manufacturers of technology equipment and components (e.g., solar panels or wind turbines) used to produce that electricity. In the former case, trade distortions are in fact harder to find due to the geographical and infrastructural limitations on crossborder electricity trade, which mainly confine it at the local or at best regional level. ${ }^{34}$ By contrast, the global nature of the RE generation equipment market means a higher probability of public support causing trade distortions and being WTO-inconsistent. ${ }^{35}$

A last but not least important aspect on which EU State aid law and WTO subsidy law differ is in terms of monitoring and enforcement mechanisms. In the EU's context, the general prohibition under Article 107(1) TFEU is backed up by

\footnotetext{
${ }^{30}$ Article 3 ASCM. For a more detailed examination, see van den Bossche and Zdouc (2017), pp. 802810.

${ }^{31}$ Articles 5(a) and 15 ASCM, referring to "material injury", or threat thereof, to the domestic industry of another member producing the like product. For a more detailed examination, see van den Bossche (2017), pp. 811-817.

$32 \mathrm{lbid}$, Articles 5(c) and 6.3, referring to "serious prejudice", or threat thereof, to the interests of another member, including by "displacing or impeding" imports of a like product into the market of the subsidising member, or by "displacing or impeding" exports of a like product into the market of a third country, or by resulting in "significant" price undercutting, price suppression, price depression or loss of sales. For a more detailed examination, see van den Bossche (2017), pp. 818-837.

33 On the discriminatory effects of LCRs see, among others, Hestermeyer and Nielsen (2014), pp. 553-591. On the limited evidence regarding their added environmental benefits, see Kuntze J-C and Moerenhout T (2013), Local Content Requirements and the Renewable Energy Industry - A Good Match?, https://pdfs.semanticscholar.org/6872/7a8d62a9722b28a250bef0470aeb847108f9.pdf (last accessed 6 February 2018), pp. 1-2, 31-35 and 43-44.

${ }^{34}$ According to the International Energy Agency, while steadily increasing, global imports (726 TWh) of electricity in 2015 only amounted to about 3.5 per cent of the world' $s$ total electricity consumption (20200 TWh): IEA Electricity Information: Overview (2017), pp. 5 and 7-8, https://www.iea.org/publications/freepublications/publication/Electricitylnformation20170verview.pdf (last accessed 6 February 2018).

${ }^{35}$ On how the distinction among RE subsidies based on the product being subsidized (namely, electricity vs. green technology products) has a bearing on the trade-distortive effects analysis under the ASCM, see Section 4 below.
} 
sophisticated procedures for ex ante and ex post centralised control by a supranational independent agent -the European Commission. ${ }^{36}$ As a general rule, EU Member States are required to notify their planned State aid measures (including material alterations to existing aid) to the Commission, which has exclusive competence for assessing their compatibility with the internal market. Critically, any such aid can only be granted after obtaining the Commission's approval. ${ }^{37}$ The implementation of unauthorised State aid is therefore unlawful and the Commission is empowered to suspend the relevant aid measure and order the full repayment of any aid already granted. ${ }^{38}$ Similarly, the Commission may open a formal investigation procedure for any authorised State aid used in contravention of its approval decision (misused aid), and in such cases has similar powers of suspension and recovery as in the case of unlawful aid. Moreover, any existing aid is subject to regular reporting and continuous review by the Commission. ${ }^{39}$

The WTO context offers nothing comparable in terms of institutional and procedural mechanisms for ensuring compliance with the ASCM. The Committee on Subsidies and Countervailing Measures is the closest to a surveillance body for matters relating to the operation of the ASCM but lacks any ex ante or ex post control powers similar to those assigned to the European Commission. Composed of governmental representatives, ${ }^{40}$ it keeps track of all notified subsidies and simply affords WTO members the opportunity to request additional information in cases of low or nil reporting performances and exchange views on such measures. ${ }^{41}$ Notification requirements under the ASCM are, in turn, quite slim inasmuch as WTO members are only requested to notify yearly all specific subsidies once they are in place, that is, after implementation. ${ }^{42}$ Even so, the rate of compliance with this

\footnotetext{
${ }^{36}$ Article 108 TFEU; and Council Regulation (EU) No 2015/1589 of 13 July 2015 laying down detailed rules for the application of Article 108 TFEU, OJ [2015] L248/9.

${ }^{37}$ Article 108(3) TFEU. One exception to this general rule is provided in: Commission Regulation (EU) No 1407/2013 on the application of Articles 107 and 108 TFEU to de minimis aid, OJ [2013] L352/1. For all covered sectors (Article 1), State aid may be granted up to a ceiling $€ 200,000$ per single undertaking over any period of three fiscal years, or $€ 100,000$ in the road transport sector (Article 3). Any such de minimis aid is deemed not to distort competition nor affect intra-EU trade, and thus does not meet the criteria of Article 107(1) TFEU and does not need to be notified under Article 108(3) TFEU. ${ }^{38}$ By contrast, WTO remedies are prospective, probably reflecting the idea that the system is designed primarily to protect current and future trade flows: Flett (2008), p. 449.

${ }^{39}$ For a more detailed examination, see Bacon (2013), chapter 18.

40 Article 24.1 ASCM.

${ }^{41}$ Article 25.9 to Article 25.11 ASCM.

42 Article 25.1 and Article 25.2 ASCM.
} 
procedural obligation is very poor, ${ }^{43}$ the information provided mainly inconsistent, ${ }^{44}$ and the amount of subsidization largely understated. ${ }^{45}$ Finally, enforcement of WTO subsidy rules is decentralized and much less systematic compared to the EU context to the extent that it depends on whether WTO members decide to take action against a specific support programme under the so-called multilateral track (that is, by filing a complaint in the WTO dispute settlement system). ${ }^{46}$ Alternatively, and in contrast to the EU State aid law, WTO members may choose the so-called unilateral track, which allows the imposition of countervailing duties (CVDs) on the part of national investigating authorities with a view to offsetting the trade-distortive effects of certain subsidies. ${ }^{47}$ Significantly, governments have by far preferred such an unilateral option to remedy the injurious effects of RE subsidies in their domestic markets, most likely because of the high evidentiary burden requested on the complainants when raising subsidy claims in the WTO dispute settlement system compared to the inherent protectionist bias of national investigating authorities in charge of imposing CVDs. ${ }^{48}$ More specifically, RE subsidies have been challenged in only six WTO disputes out of the total 116 ASCM cases to date ${ }^{49}$ whereas WTO members have conducted 45 trade remedy investigations in the sole period 2006-2015. ${ }^{50}$

\section{EU Approach to Positive Integration - Balancing the Trade-distortive and Climate-friendly Effects of Green Energy Subsidies}

\footnotetext{
${ }^{43}$ According to a recent report prepared by the WTO Secretariat, the status of subsidy notifications has significantly deteriorated over the years 1995-2015. In the words of the Secretariat: "...the share of Members that notified subsidies decreased from $50 \%$ to $38 \%$ since 1995 . In addition, the share of Members that made a 'nil' notification fell significantly, from $25 \%$ to $10 \%$, in the same period. Thus, with the exception of 1995 , the share of Members making the required notifications has not exceeded $63 \%$, and generally has hovered around $58 \%$. Conversely, the share of Members not making any notification registered an important increase since 1995, from $25 \%$ to $52 . . . "$. WTO Committee on Subsidies and Countervailing Measures, Notification Requirements under the Agreement on Subsidies and Countervailing Measures - Background Note by the Secretariat, G/SCM/W/546/Rev.8, 31 March 2017, pp. 3-4.

${ }_{44}$ Many authors have stressed the need to correct for the absence of a systematic reporting and suggested new templates for WTO subsidy notifications. See, among others, Steenblik and Simon (2010).

${ }^{45}$ See, e.g. Horlick and Clarke (2017), p. 697.

${ }^{46}$ See Article 4 and Article 7 ASCM.

47 See Article V ASCM. This unilateral track is only available in the case of subsidies causing "material injury" to the domestic industry within the meaning of Article 5(a) ASCM.

${ }^{48}$ Horlick and Clarke (2017), p. 689.

${ }^{49}$ For more details, see Espa and Marín Durán (2018), pp. 629-630.

50 Kampel (2017), p. 12.
} 
As was shown in the previous section, EU State aid law and WTO subsidy law share some basic tenets of negative integration, but the former is much more constraining on government support in both substantive and procedural terms. This is so, in particular, because there is a broader prohibition on State aid under EU law with no need to prove actual trade-distortive effects, which is centrally enforced by the singularly powerful European Commission. In turn, this goes a long way in explaining why the EU's approach to State aid control is fundamentally distinct for its positive integration dimension. That is, the wide prohibition in Article 107(1) TFEU is necessarily counterbalanced by a relatively extensive system of justifications, ${ }^{51}$ which positively defines the terms and conditions under which State aid is considered legitimate and thus permitted.

The legal basis for such a positive justification is found in Articles 107(2) and (3) TFEU, which qualify the general prohibition by introducing a number of derogations for certain categories of State aid mainly in light of their purpose. These are deemed compatible with the internal market and hence admissible, ${ }^{52}$ either automatically (paragraph 2) $)^{53}$ or in most cases at the Commission's discretion (paragraph 3). ${ }^{54}$ Of most relevance to our purposes is Article 107(3) TFEU, whose key underlying principle is that decisions by the Commission on the compatibility of State aid must weigh its positive impact in reaching a set of legitimate objectives against any negative tradedistortive effects. However, the TFEU defines these objectives in rather vague terms: obvious examples are references to "aid to important projects of common European interest" (Article 107(3)(b)), and to "aid to facilitate the development of certain economic activities or of certain economic areas, where such aid does not adversely affect trading conditions to an extent contrary to the common interest" (Article 107(3)(c) TFEU). In addition, there is not much guidance on how to balance any such

\footnotetext{
${ }^{51}$ Note that the introductory words of Article 107(1) TFEU ("save as otherwise provided in the Treaties") make clear that the prohibition is not absolute.

52 In addition, the Council acting on a proposal from the Commission may to introduce further derogations if needed: Article 107(3)(d) TFEU.

${ }^{53}$ Automatic compatibility includes State aid: having a social character (Article 107(2)(a)); necessary to make good the damage caused by natural disasters or exceptional occurrences (Article 107(2)(b)); and granted to the economy of certain areas of Germany affected by the cold war division (Article 107(2)(c)). In these cases, the Commission has no discretion as to whether or not to authorize the aid, but merely ascertains that the conditions set out in Article 107(2) TFEU are fulfilled. See further, Bacon (2013), pp. 95-100.

54 Discretionary compatibility includes: cohesion aid (Article 107(3)(a)); aid to important projects of common European interest or to remedy a serious disturbance in the economy of a Member State (Article 107(3)(b)); and aid to promote culture and heritage conservation (Article 107(3)(d)). See further, Bacon (2013), pp. 100-113.
} 
objective of "common interest" against the potentially trade-distortive effects of the State aid in question. This ambiguity in EU treaty law provides the Commission with wide discretion and, as Blauberger aptly notes, enables it to "act as a supranational entrepreneur, not only in enforcing the prohibition of distortive State aid, but also developing its own vision of 'good' State aid policy ... and thus [to create] positive integration from above." 55

In our particular case, there is little doubt that combating climate change and promoting the development of renewable energy are objectives of "common interest" for the $\mathrm{EU}^{56}$ which, in certain circumstances, may justify the granting of State aid in spite of any potential distortion on competition and/or intra-EU trade. That being so, a complex system of justifications for "good" environmental State aid has been developed by the European Commission in a hybrid form, using a combination of both hard-law and soft-law instruments which have been recently reviewed following the State Aid Modernisation process initiated in May 2012. ${ }^{57}$ More specifically, there is presently a two-track approach for sheltering government support to renewable energy from the general prohibition in Article 107(1) TFEU: either under (i) the general 2014 General Block Exemption (GBE) Regulation, ${ }^{58}$ which automatically authorizes State aid under certain conditions without prior notification and individual scrutiny by the Commission; 59 or if not eligible under this Regulation, under (ii) the specific 2014-2020 Guidelines on State Aid for Environmental Protection and Energy, ${ }^{60}$ which set out the principles and criteria against which the Commission assesses the compatibility of notified State aid and authorizes it on a case-by-case basis.

\footnotetext{
${ }^{55}$ Blauberger M (2008), From Negative to Positive Integration? European State Aid Control through Soft and Hard Law, (Max Planck Institute for the Study of Societies Discussion Paper 08/04, http://www.mpifg.de/pu/mpifg dp/dp08-4.pdf (last accessed 6 February 2018), pp. 3 and 5.

56 See, inter alia, Articles 191 and 194(1)(d) TFEU; see also European Commission Communication on Energy 2020 - A Strategy for Competitive, Sustainable and Secure Energy, COM(2010) 639 final, 10 November 2010; and European Commission Communication on a Policy Framework for Climate and Energy in the period from 2020 to 2030, COM(2014) 15 final, 22 January 2014.

57 For more information: http://ec.europa.eu/competition/state aid/modernisation/index en.html (last accessed 6 February 2018).

58 Commission Regulation (EU) No 651/2014 of 17 June 2014 declaring certain categories of aid compatible with the internal market in the application of Articles 107 and 108 TFEU, OJ [2014] L187/1 [hereinafter 2014 GBE Regulation]. This replaced: Commission Regulation (EC) No 800/2008 declaring certain categories of aid compatible with the common market in application of Articles 87 and 88 of the Treaty, OJ [2008] L214/3 [hereinafter 2008 GBE Regulation].

592014 GBE Regulation, Preamble, para 6.

60 European Commission Guidelines on State Aid for Environmental Protection and Energy 2014-2020, OJ [2014] C 200/1 [hereinafter 2014-2020 EEA Guidelines]. Formally speaking, these are not formally binding on the Member States, but are so for practical purposes since they guide the Commission's assessment and decision-making on the compatibility of State aid with the internal market.
} 
With regards to the first track, the 2014 GBE Regulation significantly extends the margins for EU Member States to grant aid without prior notification, in an attempt to focus ex-ante compatibility assessment by the Commission only on cases with the biggest potential to distort competition and intra-EU trade. ${ }^{61}$ However, it is important to highlight that the 2014 GBE Regulation does not apply to State aid "to export-related activities towards third countries or Member States", nor "contingent upon the use of domestic over imported goods" 62 -in other words, the category of prohibited subsidies under WTO law finds no legal shelter under the Regulation. Otherwise, the scope of the current Regulation has been considerably broadened vis-à-vis its predecessor: it does not only cover "investment aid"63 for the production of energy from renewable energy resources, ${ }^{64}$ but also "operating aid" 65 for the production of electricity from renewable energy resources and of energy from renewable energy resources in smallscale installations. ${ }^{66}$ These RE support measures must, in turn, meet a number of general ${ }^{67}$ and category-specific conditions in order to be block exempted under the Regulation, which are briefly outlined next.

Investment aid for renewable energy needs to be below the specified notification threshold of $€ 15$ million per undertaking per investment project, ${ }^{68}$ which implies a remarkable increase vis-à-vis the 2008 GBE Regulation (i.e., $€ 7.5$ million per undertaking per investment project). ${ }^{69}$ In addition, it can only be granted to new installations and shall be independent from output, ${ }^{70}$ as well as within the specified maximum aid intensities: $30-45 \%, 55 \%$ and $65 \%$ of eligible costs ${ }^{71}$ respectively for

61 European Commission Memo - State Aid: Commission adopts new General Block Exemption Regulation' (14/369), dated 21 May 2014 [hereinafter Commission Memo 2014], p. 2, estimating that "3/4 of today's aid measures and about 2/3 of total aid amounts granted by Member States could be covered by the new GBER."

622014 GBE Regulation, Articles 1(2)(c) and (d); similarly, 2008 GBE Regulation, Articles 2(a) and (b). 63 Usually referring to one-off aid measures covering upfront capital costs of investing in the production of energy from renewable energy sources (e.g., grants and preferential loans).

64 Defined as "renewable non-fossil energy sources": wind, solar, aerothermal, geothermal, hydrothermal and ocean energy, hydropower, biomass, landfill gas, sewage treatment plant gas and biogases: 2014 GBE Regulation, Article 2 (110).

65 Usually referring to aid measures covering production-based costs of renewable energy generation (e.g., price-support instruments).

662014 GBE Regulation, Articles 41-43. Cf. 2008 GBE Regulation, Article 23, covering only investment aid for the promotion of energy from renewable energy sources.

${ }^{67}$ E.g., on "transparent aid": 2014 GBE Regulation, Article 5.

$68 \mathrm{Ibid}$, Article 4(1)(s).

692008 GBE Regulation, Article 6(1)(b).

702014 GBE Regulation, Article 41(5).

712014 GBE Regulation, Article 41(6), these are the extra investment costs to promote the production of energy from renewable sources. 
large, medium-sized and small enterprises. ${ }^{72}$ Operating aid to the green electricity production should be granted, as a general rule, through a competitive bidding process open to all green electricity generators on a non-discriminatory basis, ${ }^{73}$ in which case the notification threshold is set at a total of $€ 150$ million per year. ${ }^{74}$ As will be seen below, this competitive allocation of public support is in line with the Commission's drive towards the gradual integration of matured $R E$ technologies into the internal electricity market in the 2014-2020 EEA Guidelines.

According to the European Commission, the above-indicated thresholds on both the amount and intensity of renewable energy aid were derived from "[its] market experience and decision-making practice, in particular from the application of State aid frameworks and guidelines". ${ }^{75}$ The underlying assumption appears to be that any potentially distortive effects of renewable energy aid exempted under the GBE Regulation are limited and outweighed by its benefits in contributing to the common objective of climate change mitigation, insofar as it is contained within the established ceilings and other conditions. ${ }^{76}$ To ensure this, any green aid granted by EU Member States pursuant to the GBE Regulation is subject to transparency and reporting obligations so that the Commission can exercise ex post control of such measures. ${ }^{77}$ According to the Commission's 2016 State Aid Scoreboard, about 95\% of State aid measures implemented by Member States have been exempted under the 2014 GBE Regulation, with the general category of "environmental protection and energy savings" taking up the largest combined expenditure (9.5 billion in 2015). ${ }^{78}$

Turning to the second track, the 2014-2020 Guidelines on State Aid for Environmental Protection and Energy extend the scope of the previous 2008

\footnotetext{
722014 GBE Regulation, Articles 41(7) and (8). These maximum aid intensities are roughly the same as those found under the former 2008 GBE Regulation, Article 23(2). However, under the 2014 GBE Regulation, these may go up to $100 \%$ of eligible costs, if the aid is granted in a competitive bidding process on the basis of clear, transparent and non-discriminatory criteria (Article 41(10)).

732014 GBE Regulation, Article 42(2). Nonetheless, under Articles 42(3) and (4), EU Member States may limit the bidding process to specific RE technologies under certain conditions (e.g., if necessary to achieve diversification or secure grid stability). In addition, under Article 42(8), a special exemption is made for small-scale installations producing electricity from renewables, whereby operation aid may be granted in the absence of a competitive tendering process but may not exceed $€ 15$ million per undertaking.

${ }^{74} 2014$ GBE Regulation, Article 4(1)(v).

75 Commission Memo 2014, p. 1.

762014 GBE Regulation, Preamble, paras 16 and 61.

772014 GBE Regulation, Chapter II.

78 European Commission State Aid Scoreboard 2016, http://ec.europa.eu/competition/state aid/scoreboard/index en.html. No specific data on renewable energy aid is available.
} 
Guidelines on State Aid for Environmental Protection ${ }^{79}$ in the energy field (e.g., to cover aid for energy infrastructure and aid for generation adequacy measures), ${ }^{80}$ but adopt a more stringent approach on government support to renewable energy. Like its predecessor, the 2014-2020 EEA Guidelines cover both investment and operating aid that does not fall within the scope of the 2014 GBE Regulation and such aid must therefore be notified ex ante to the Commission. ${ }^{81}$ However, there is no explicit exclusion of State aid contingent upon export performance or import substitution meaning that prohibited subsidies under WTO law could, in principle, be sheltered under the EEA Guidelines (unlike under the 2014 GBE Regulation). ${ }^{82}$ All environmental/energy aid measures authorised under these Guidelines are subject to annual reporting and monitoring by the Commission. ${ }^{83}$

The 2014-2020 EEA Guidelines provide "Common Assessment Principles", which lay out an overarching "balancing test" 84 as the principal basis for the Commission's compatibility assessment of all notified environmental/energy aid measures. It comprises seven elements: (i) contribution to an objective of common interest; 85 (ii) need for State intervention;86 (iii) appropriateness of aid;87 (iv) incentive effect of aid; 88 (v) proportionality of aid; 89 (vi) avoidance of undue negative effects on

\footnotetext{
${ }^{79}$ European Commission Community Guidelines on State Aid for Environmental Protection, OJ [2008] C 82/1 [hereinafter 2008 Guidelines].

80 2014-2020 EEA Guidelines, section 1.2.

81 Article 108(3) TFEU.

82 2014-2020 EEA Guidelines, section 1.1(15).

83 2014-2020 EEA Guidelines, section 6.

84 This test was first set out in: European Commission State Action Plan - Less and better targeted State aid: a road map for State aid reform 2005-2009, COM(2005) 107 final, 7 June 2005. It has been subsequently developed in the Commission's guidelines: see e.g., 2008 Guidelines, section 1.3.

85 2014-2020 EEA Guidelines, section 3.2.1, whereby the planned State aid should be aimed at an objective of common interest in accordance with Article 107(3) TFEU (in this context, the shift towards a resource-efficient and low-carbon economy, and achieving a well-functioning, secure, affordable and sustainable European energy market).

86 2014-2020 EEA Guidelines, section 3.2.2, whereby the planned State aid targets a market failure and can bring about a material contribution towards achieving the specified environmental or energy objective that the market alone cannot deliver.

87 2014-2020 EEA Guidelines, section 3.2.3, whereby there are no less-trade distortive policy instruments or types of aid that would make an equivalent contribution to the sought environmental or energy objective.

88 2014-2020 EEA Guidelines, section 3.2.4, whereby the proposed State aid measure induces the beneficiary to change its behaviour to increase the level of environmental protection or to improve the functioning of a secure, affordable and sustainable energy market, and such a change in behaviour would not have occurred but for the aid.

89 2014-2020 EEA Guidelines, section 3.2.5, whereby the planned State aid is limited to the minimum necessary to achieve the environmental or energy objective aimed for.
} 
competition and intra-EU trade; 90 (vii) transparency of aid. ${ }^{91}$ In addition, compatibility criteria are specified for certain categories of aid..$^{92}$ Of most relevance for present purposes are those applicable to operating aid to green electricity production, which have been considerably strengthened vis-à-vis the 2008 Guidelines. In essence, the current EEA Guidelines promote a progressive convergence of public support for green electricity across the EU through the gradual introduction of market-based aid instruments and allocation mechanisms.

As a first step, for all new aid measures adopted after 1 January 2016, generators have to sell their green electricity directly in the market, and aid may only be granted as a premium in addition to the market price. ${ }^{93}$ In other words, the Guidelines seek to phase out feed-in tariff schemes commonly used by EU Member States, which guarantee the purchase of renewably generated electricity at administratively-fixed minimum prices, and replace these by feed-in premiums that expose green electricity generators to market signals and changing electricity prices. ${ }^{94}$ In a second step, the Guidelines have gradually introduced competitive bidding as the principal means for granting aid to green electricity producers. ${ }^{95}$ Roughly speaking, this is a market-based mechanism for setting the premium price. From 1 January 2017, such a competitive bidding process became the general rule for allocating all operating aid granted (i.e., $100 \%$ of the planned new green electricity capacity). ${ }^{96}$ In principle, this process should be technology-neutral and open to all generators producing

\footnotetext{
90 2014-2020 EEA Guidelines, section 3.2.6, whereby the negative effects of the planned State aid measure in terms of distortions on competition and intra-EU trade must be limited and outweighed by the positive effects in terms of contribution to the sought environmental or energy objective, so that the overall balance is positive.

91 2014-2020 EEA Guidelines, sections 3.2.7 and 6.

92 See 2014-2020 EEA Guidelines, Annex I, laying down maximum aid intensities for RE investment aid that are similar to the ones previously seen under the GBE Regulation: $45 \%, 55 \%$ and $65 \%$ of eligible costs respectively for large, medium-sized and small enterprises, with the possibility of reaching $100 \%$ for aid provided following a competitive bidding process on the basis of clear, transparent and non-discriminatory criteria (section 3.2.5.1 (80)).

93 2014-2020 EEA Guidelines, section 3.3.2.1(124). In addition, beneficiaries are subject to standard balancing obligations and measures must be in place to ensure they have no incentive to generate electricity under negative prices.

${ }_{94}$ European Commission Staff Working Document - Guidance for the Design of Renewable Support Schemes, SWD(2013) 439 final [hereinafter Commission WD 2013], pp. 8-9 and 12-13.

95 During a transitional phase covering the years 2015 and 2016, aid for at least $5 \%$ of the planned new green electricity capacity had to be provided through a competitive bidding process on the basis of clear, transparent and non-discriminatory criteria: 2014-2020 EEA Guidelines, section 3.2.5.1(126).

$96 \mathrm{lbid}$, section 3.2.5.1(126). Only under a limited number of circumstances are Member States still allowed to grant aid without such an allocation process (e.g., to avoid strategic bidding or underbidding).
} 
electricity from renewable energy sources on a non-discriminatory basis. ${ }^{97}$ Support schemes compatible with these conditions are authorised for a maximum period of ten years, and if maintained after such a period, should be re-notified and re-evaluated by the Commission. ${ }^{98}$

This drive towards harmonising the form and means of allocating public support to green electricity generation certainly implies a departure from the more decentralised approach initially adopted under the 2009 Renewable Energy Directive, ${ }^{99}$ and has been enshrined in the 2016 Commission's proposal for a revised Directive within the Union's 2030 climate and energy framework. ${ }^{100}$ According to the Commission, such a move is now justified and indispensable in order to adjust current support schemes to the growing share of renewables in the European electricity market and the decreasing costs of more established RE technologies. ${ }^{101}$ In particular, the Commission is concerned that the rigidity of administratively established FIT prices fails to take account of falling production costs, risking thereby overcompensating green electricity producers. In addition, by fully insulating beneficiaries from market price signals, FIT schemes have led to excessive production of renewably generated electricity irrespective of actual demand. ${ }^{102}$ The basic premise is, therefore, that renewables should be gradually integrated into the internal electricity market through more flexible feed-in premiums, and government support phased out as RE technologies mature and become grid-competitive. ${ }^{103}$ In this sense, the Commission

\footnotetext{
$97 \mathrm{lbid}$, section 3.3.2.1(126), in which case, the Commission will presume that the aid is proportionate and does distort trade and competition to an extent contrary to the common interest. However, Member States may still carry out RE technology-specific tenders under certain conditions (e.g., if necessary to promote the long-term potential of a new and innovative technology or to achieve diversification or secure grid stability).

98 Ibid, section 3.3.1(121). In addition, the Guidelines promote cross-border cooperation with the Commission giving positive consideration to operating aid schemes for green electricity that are open to other EEA countries and Contracting Parties of the Energy Community: section 3.3.1(122).

99 Directive 2009/28/EC of the European Parliament and of the Council of 23 April 2009 on the promotion of the use of energy from renewable sources, OJ [2009] L140/16 [hereinafter 2009 Renewable Energy Directive], Article 3(3), leaving the choice of support instruments to the EU Member States in order to achieve their national renewable energy targets for 2020. For a discussion, see Marín Durán (2018), pp. 136-138; and Callaerts (2015), pp. 17-18.

100 European Commission Proposal for a Directive of the European Parliament and of the Council, $\operatorname{COM}(2016) 767$ final/2, 23 February 2017 [hereinafter 2016 Proposed RE Directive]. In particular, Article 4 provides that "[s]upport for electricity from renewable sources shall be designed so as to integrate electricity from renewable sources in the electricity market and ensure that renewable energy producers are responding to market price signals and maximise their market revenues" and that "Member States shall ensure that support for renewable electricity is granted in an open, transparent, competitive, non-discriminatory and cost-effective manner".

101 Commission WD 2013, p. 4.

102 Commission Memo 2014, p. 2.

103 Commission WD 2013, p. 22.
} 
sees genuinely competitive bidding as a self-regulating subsidy phase-out mechanism, which will reward low-cost $R E$ technologies and eventually approach zero as technology costs reach grid parity. ${ }^{104}$

In sum, positive integration has gone hand in hand with negative integration in the EU's regulatory approach to RE subsidies, recognising the need to strike a delicate balance between their trade-distortive (negative) and climate-friendly (positive) effects. Both forms of integration have entailed the establishment of common substantive rules and institutional mechanisms, albeit the former to generally abolish the use of State aid within the EU internal market while the latter to permit certain categories of "good" State aid (i.e., whose trade-distortive impact is outweighed by their contribution to climate change mitigation among other public policy objectives). And yet, as evidenced by the 2014 GBE Regulation and 2014-2020 EEA Guidelines, drawing a bright line between "good" (and hence, justifiable) and "bad" (and hence, unjustifiable) RE subsidies is a highly complex regulatory endeavour, requiring consensus on a sufficiently detailed and quite technical set of criteria. This helps explaining why the positive integration dimension has been developed more gradually, and mainly driven by the European Commission who enjoys extensive and exclusive powers in the field of EU State aid law that are not easily matched within other centralized systems of subsidy control (including the WTO).

\section{The Absence of a Balancing Mechanism in WTO Subsidy Law - Is It a Problem?}

The ASCM does not contain anything similar to the sophisticated two-track approach developed in the EU context for balancing the negative (trade-distortive) and positive (climate-friendly) effects of renewable energy subsidies. Its trade-injury focus does not allow for any negative externalities other than trade distortions to be taken into account, ${ }^{105}$ and hence RE subsidies will be ASCM-incompatible whenever they cause trade distortions, be it actual (as in the case of actionable subsidies) or presumed (as in the case of prohibited subsidies), irrespective of any environmental benefits they

\footnotetext{
104 Commission WD 2013, p 7. Nevertheless, the Commission recognises that market integration may not be appropriate for small installations, which benefit from a differentiated regime under the 20142020 Guidelines (notably, no competitive bidding process is required and FITs and other equivalent forms of support are still allowed: 2014-2020 Guidelines, sections 3.2.2.2(131) and 3.3.2.1(125).

105 Horlick and Clark (2017), p. 678.
} 
may bring. ${ }^{106}$ Originally, this was mitigated to some extent by the existence of a specific exception, Article 8 ASCM, which created a category of non-actionable (that is, permitted) subsidies that included, among others, certain (narrowly defined) environmental subsidies. ${ }^{107}$ As it is known, however, Article 8 ASCM was negotiated as a provisional 5-year exception and it expired on 1 January 2000 after WTO members failed to renew it. ${ }^{108}$ The fate of Article 8 ASCM again shows how inherently difficult it is for over 160 States to agree on what should be the conditions for granting the "green light" to certain support schemes based on their purpose, even when the underlying policy objective is itself of undisputed legitimacy and urgency as it is the case with climate change mitigation.

Failing anything similar to an environmental exception suited to shelter RE subsidies under the ASCM, the question is whether the absence of a positive integration dimension in the ASCM risks materializing into a clash between the multilateral trade and climate change regimes. Otherwise said, do ASCM disciplines, as they stand now, outlaw climate-desirable RE subsidies, thus running counter to the mutual supportiveness between international trade and climate change regimes? ${ }^{109}$ Here the answer is mixed and ought to be qualified in light of the specific measures at issue, the product being subsidized and the most proximate objectives pursued. ${ }^{110}$

At the one end of the spectrum are discriminatory RE subsidies, that is, support schemes that incorporate local content requirements. Such LCRs make the subsidy programme "contingent on local content" and are thus prohibited outright as per Article 3 ASCM without the need to prove their actual trade distortive effects, in addition to violating national treatment rules in other WTO agreements. ${ }^{111}$ Not surprisingly, discriminatory RE subsidies have been the sole target of WTO renewable energy

\footnotetext{
106 Horlick and Clarke (2017), p. 676.

107 See Article 8.2 (c) ASCM, which deemed non-actionable those subsidies granting "assistance to promote adaptation of existing facilities to new environmental requirements imposed by law and/or regulations which result in greater constraints and financial burden on firms, provided that the assistance: (i) is a one-time non-recurring measure; and (ii) is limited to 20 per cent of the cost of adaptation; and (iii) does not cover the cost of replacing and operating the assisted investment, which must be fully borne by firms; and (iv) is directly linked to and proportionate to a firm's planned reduction of nuisances and pollution, and does not cover any manufacturing cost savings which may be achieved; and $(\mathrm{v})$ is available to all firms which can adopt the new equipment and/or production processes".

${ }^{108}$ For a thorough reconstruction of the negotiating history of Article 8 ASCM and the reasons for its expiration, see in particular Bigdeli (2011).

109 For a more in-depth discussion and contextualisation of this issue, see Espa and Marín Durán (2018), pp. 633-643.

${ }^{110} \mathrm{~A}$ thorough explanation of how such distinctions play out for the purpose of assessing how different RE subsidies would fare under the ASCM is given in Espa and Marín Durán (2018), pp. 623-628.

111 See above, Section 2.
} 
disputes to date. ${ }^{112}$ Interestingly, moreover, WTO members have gradually privileged national treatment claims based on Article III:4 GATT and Article 2.1 TRIMs rather than ASCM claims revolving around Article 3. ${ }^{113}$ Accordingly, the Appellate Body has consistently condemned the discriminatory component of the challenged RE subsidies under the GATT/TRIMs non-discrimination rule only. ${ }^{114}$ However, such an outcome does not raise issues from a mutual supportiveness perspective inasmuch as LCRs are essentially industrial policy instruments aimed at encouraging local RE industries albeit less competitive. ${ }^{115}$

At the other hand of the spectrum are non-discriminatory support programmes targeting green electricity itself, such as FIT schemes. Such programmes, in and of themselves, are on a comparatively safer footing under existing ASCM disciplines. First, as previously explained, it seems harder (albeit not impossible) for FIT schemes to be subject to ASCM disciplines due to the flexibility built-in through the Appellate Body's interpretative approach to the benefit analysis in Canada - Renewable Energy (2013). ${ }^{116}$ Second, it is not readily obvious for FIT programmes to be found to cause trade-distortive effects inasmuch as cross-border electricity trade still remains geographically confined for both geographical and infrastructural reasons. ${ }^{117}$ Yet, assuming there were two or more WTO members trading in electricity, there is a chance that adverse effects be found in the form of "serious prejudice" to the trade

\footnotetext{
112 For a detailed explanation of how the so-called likeness of success argument conditions the choice of disputes, see D. de Bièvre et al (2017).

113 In the India -Solar Cells dispute (2016), the US withdrew the claim that the Indian feed-in tariff scheme at issue was inconsistent with Article 3 ASCM from its second request for consultations (intervened after the Appellate Body's ruling in Canada - Renewable Energy (2013)), and decided to keep its claims under Article III:4 GATT and Article 2.1 TRIMs only. See WTO Appellate Body Report, India - Certain Measures Relating to Solar Cells and Solar Modules, adopted 14 October 2016, WT/DS456/AB/R [Appellate Body Report, India - Solar Cells (2016)]. For more details, see Asmelash (2015), pp. 277-8.

${ }_{114}$ Appellate Body Report, Canada - Renewable Energy (2013); Appellate Body Report, India - Solar Cells (2016). It should however be noted that, in the former case, the Ontario government ended up removing its FIT scheme altogether for lack of political support otherwise. For more details, see T. Meyer (2018).

115 Especially in the short- to medium-run, the environmental benefits linked to the use of LCRs are highly disputed. See, among others, Casier C and Moerenhout T (2013), WTO Members, Not the Appellate Body, Need to Clarify the Boundaries in Renewable Energy Support, https://www.iisd.org/pdf/2013/wto members renewable energy support.pdf (last accessed 6 February 2018), pp. 1-2, 31-35 and 43-44.

${ }_{116}$ For a more detailed explanation, see Espa and Marín Durán (2018), pp. 633-634.

117 Although trade in electricity has been expanding in latest years thanks to technological improvements and investment choices (see, e.g., Chatzivasileiadis and Ernst (2017), pp. 21-45), global imports of electricity only account for a negligible $3.5 \%$ of the world's total final electricity consumption. See IEA Electricity Information: Overview (2017), https://www.iea.org/publications/freepublications/publication/Electricitylnformation20170verview.pdf (last acceded 6 February 2018), pp. 5 and 7-8.
} 
interests of another WTO member under Article 5(c) ASCM. FIT-subsidized green electricity tends in fact to be mainly, and at times directly, ${ }^{118}$ absorbed at the national level, thus having the effect of reducing the consumption of imported electricity (even if cheaper) compared to what would have been the case under normal market situations. ${ }^{119}$ Could this be proven, FIT schemes would be considered unlawful under Article 6.3(a) ASCM as subsidies whose effect is "to displace or impede the imports of a like product of another Member into the market of the subsidizing Member". ${ }^{120}$ Such a possibility, as slim as it may be, ${ }^{121}$ is non-desirable from a mutual supportiveness perspective to the extent that FIT schemes are classically considered as the archetypal "good" type of RE subsidies ${ }^{122}$ and the most efficient and effective tool for promoting green electricity generation. ${ }^{123}$

In between are a wide range of fiscal and financial incentives given by governments to manufacturers of green technology equipment. ${ }^{124}$ Such measures are likely to be covered by the ASCM, ${ }^{125}$ and, albeit formally non-discriminatory, they could still de facto discriminate in favour of domestic producers given the usually less significant penetration of foreign companies/installations in the territory of the subsidizing Member. ${ }^{126}$ In addition, ASCM-inconsistency scenarios either revolving around "serious prejudice" claims or "material injury" claims would have a

\footnotetext{
118 This happens in those countries where priority access and priority dispatch are also granted to green electricity, such as in the case of EU Members States until the reform of the Renewable Energy Directive will enter into force. For more details, see Espa (2017b), pp. 225-244.

119 See on this point, Advocate General Bot in the Case 573/12, Ålands Vindkraft, judgement of 1 July 2014 [ECLI:EU:C:2014:2037], paras. 75-76.

120 It should be noted, however, that based on existing WTO case law a "genuine and substantial relationship" between the FIT scheme itself and the current (or imminent) trade distortion must be shown as evidence of causation (that is, the effect of the scheme must be clearly disentangled from those of any other instruments supporting green electricity). For an analysis of the difficulties inherent to this exercise in the case of green electricity, see Espa and Marín Durán (2018), p. 638.

121 See Espa and Marín Durán (2018), pp. 637-639, for a detailed examination of all factors that are likely to exclude that a WTO dispute concerning a non-discriminatory FIT scheme actually materializes. 122 See, e.g., Cosbey and Mavroidis (2014), p. 28.

123 See, among others, IPCC Renewable Energy Sources and Climate Change Mitigation - Summary for Policy Makers and Technical Summary (2012), https://www.ipcc.ch/pdf/specialreports/srren/SRREN FD SPM final.pdf (last accessed 2 September 2017), p. 152. It should be noted, however, that countries are gradually phasing out costly out-of-market price-support mechanisms such as FIT programmes in favour of more sustainable, market-based mechanisms for setting premium prices such as competitive tendering. See, for all, IRENA (2017), Rethinking Energy 2017: Accelerating the Global Energy Transformation, http://www.irena.org/DocumentDownloads/Publications/IRENA REthinking Energy 2017.pdf (last accessed 6 February 2018), pp. 23-24.

${ }_{124}$ An overview of such measures is given in Espa and Marín Durán (2018), pp. 623-628.

125 Espa and Marín Durán (2018), pp. 639-640.
}

126 UNEP (2014), Trade and Green Economy: Handbook, http://www.unep.org/greeneconomy/sites/unep.org.greeneconomy/files/trade-ge-handbook-final-fullweb 0.pdf (last accessed 2 September 2017), p. 105. 
comparatively higher chance to succeed due to the global reach of the market for green technology products. ${ }^{127}$ WTO members, however, have overall refrained from raising ASCM claims and preferred instead to unilaterally impose offsetting CVDs (and often parallel anti-dumping duties). ${ }^{128}$ This choice may have to do with the fact that, as more recent practice shows, domestic investigating authorities have generally not been much inclined to engage in a balancing exercise that would allow to consider any positive (climate change-mitigation) effects produced by public incentives given to manufacturers of green technology products against their negative (trade-distortive) effects when deciding whether to introduce or maintain CVDs and calculating their exact rate. ${ }^{129}$

To sum up, when compared to EU State aid law, WTO subsidy disciplines are less constraining on governmental support to renewable energy. Unlike in the EU context, RE subsidies are not in principle subject to a general prohibition under WTO law, but exposed to varying degrees of legal risks under the ASCM depending on whether they incorporate LCRs (i.e., always WTO-illegal) and on whether they target electricity itself (i.e., less likely WTO-inconsistent) or rather green technology products (i.e., more likely WTO-inconsistent). This means that the need for positive integration is not as fundamental in the WTO context as it is in the EU one, and instead needs to be calibrated against the spectrum of legal risks. Nonetheless, the case for introducing a balancing mechanism in the ASCM may still hold true in those situations where 'good' RE subsidies (i.e., whose trade-distortive effects can be presumed to be limited and outweighed by their benefits in contributing to climate change mitigation) still face high legal risks under current ASCM rules. This being so, the next section explores which lessons (if any) may be drawn for the WTO from the EU regulatory experience in terms of positive integration.

\section{What, If Anything, May the WTO Learn from the EU?}

In the aftermath of the WTO Canada - Renewable Energy (2013) dispute, two main options for reforming the ASCM have been often advocated in the scholarship: (i)

\footnotetext{
127 See, respectively, Article 6.3 ASCM and Article 5(a) ASCM. For more details, see Espa and Marín Durán (2018), pp. 640-641.

${ }^{128}$ For a thorough analysis of the numerous CVD and antidumping investigations concerning green technology products, see Vermulst and Meng (2017), pp. 336-355.

129 See, among others, Espa and Marín Durán (2018), pp. 642-643; and Horlick and Clarke (2017), p. 689.
} 
resuscitating (or negotiating anew) the category of permissible subsidies along the lines of the now expired Article 8 ASCM; and (ii) extending the applicability of Article XX GATT or introducing a similar exception clause in the ASCM as a means to justify otherwise unlawful subsidies. ${ }^{130}$ Interestingly, the former follows the logic of full exemption under the GBE Regulation, whereas the latter replicates the case-by-case assessment approach under the EEA Guidelines. ${ }^{131}$

The re-introduction of the category of non-actionable subsidies would have the merit to shelter qualifying RE subsidies from both multilateral and unilateral trade remedial action but would require the pre-determination of specific conditions granting eligibility for this full exemption. While it is unanimously recognized that the limited scope of the original Article 8.2(c) ASCM would not offer any protection to those RE subsidies still exposed to ASCM-inconsistency, ${ }^{132}$ the question is whether this may be reverted were a new exemption for RE subsidies be negotiated from scratch. In this respect, some scholars have suggested that the EU experience could serve as an inspiration with a view to broadening the scope of exempted RE subsidies along the lines of the GBE Regulation. ${ }^{133}$ Yet, one should bear in mind that there are several factors why the EU's regulatory approach may be difficult to transpose to the WTO. First, the WTO membership is much wider and more heterogeneous than that of the EU, thus making it way more challenging for them to agree on pre-determined (general and category-specific) conditions for the purposes of defining non-actionable RE subsidies. ${ }^{134}$ This seems confirmed if one considers that WTO members did not even agree to renew the limited Article 8 ASCM itself after having designed the category of permissible subsidies only five years earlier. ${ }^{135}$ Second, as shown by the EU experience, broadening the scope for exempting RE subsidies requires a much stronger institutional setting than it is available in the WTO context in terms of both abuse-prevention rules and surveillance procedures. ${ }^{136}$ Such inherent limits to

\footnotetext{
${ }^{130}$ Both proposals are examined at length in Espa and Marín Durán (2018), pp. 643-650.

131 See above, Section 2. For more details, see Marín Durán (2018), pp. 159-160.

132 See above, Section 2. For more details, Marín Durán (2018), p. 160.

133 See, e.g. L. Rubini (2012), p. 577, and Rubini L (2015), Rethinking International Subsidies Disciplines: Rationale and Possible Avenues for Reform, http://e15initiative.org/publications/rethinkinginternational-subsidies-disciplines-rationale-and-possible-avenues-for-reform (last accessed 10 February 2018), pp. 4-5.

${ }^{134}$ For more, see Marín Durán (2018), p. 160.

135 See Bigdeli (2011), p. 20.

${ }^{136}$ Bigdeli (2011), pp. 20 and 36. For a discussion on how the European Commission's powers are uniquely distinct, see Marín Durán (2018), p. 161.
} 
replicating the EU example are implicitly acknowledged in existing proposals inasmuch as they either remain very general (namely, by simply stating that RE subsidies aimed at promoting the use of clean energy should be kept distinct from RE subsidies targeting domestic RE manufacturing) or suggest that eligibility criteria should be clearly designed in a way as to shelter minimally-distortive RE subsidies only, with no definitive answer however as to how to treat unavoidable "boundary" cases. ${ }^{137}$ Finally, and significantly, the need for more stringent transparency and notification requirements, on the one hand, and stricter procedural safeguards to avoid abuses, on the other hand, is also extensively reiterated. ${ }^{138}$

Some of the difficulties inherent to pre-determining sufficiently calibrated criteria for carving out RE subsidies would be overcome through recourse to a general exception clause à la Article XX GATT, whose conditions would be formulated in general terms and interpreted flexibly on a case-by-case basis by a multilateral but non-political decision-maker -i.e., the WTO adjudicatory bodies. ${ }^{139}$ A strand of the literature has even argued in favour of making Article XX GATT itself applicable to ASCM-inconsistent subsidies. ${ }^{140}$ Such a scenario would be attractive in that it would not require a formal amendment of the ASCM, but the matter is far from being settled. ${ }^{141}$ Yet, assuming on arguendo that Article XX GATT is available, whether it would indeed serve to provide a legal shelter to climate-desirable RE subsidies otherwise at risk under the ASCM is far from clear. In particular, the limits of a GATT Article XX-based approach are evident when compared to the "balancing test" designed in the 2014-2020 EEA Guidelines. Both potentially relevant "environmental"

\footnotetext{
137 Among the more structured proposals, see Shadikhodjaev (2015), pp. 494-496 and Horlick and Clarke (2016), p. 11. For a more detailed account, see Espa and Marin Duran (2018), pp. 649-650.

${ }^{138}$ Espa and Marin Duran (2018), p. 650.

139 See Marín Durán (2018), p. 161.

140 See, e.g. Rubini (2012), pp. 561-566; Howse R (2013), Securing Policy Space for Clean Energy under the SCM Agreement: Alternative Approaches, http://e15initiative.org/publications/securingpolicy-space-for-clean-energy-under-the-scm-

agreement-alternative-approaches/ (last accessed 6 February 2018), p. 2; Shadikhodjaev (2015), pp. 499-505; and, more recently, Condon (2017), pp. 685-690.

141 The direction indicated by the Appellate Body in recent WTO case law, however, seems hardly open to such an interpretation. In particular, the Appellate Body has clarified that GATT Article XX defences can be available to violations of non-GATT provisions only to the extent that such provisions incorporate specific language to that effect (that is, in the form of an "objective" textual link). See WTO Appellate Body Report, China - Measures Related to the Exportation of Various Raw Materials, WT/DS394/DS395/DS398/AB/R, adopted 22 February 2012, paras. 303-306; and WTO Appellate Body Report, China - Measures Related to the Exportation of Rare Earths, Tungsten and Molybdenum, WT/DS431/DS432/DS433/AB/R, adopted 29 August 2014, paras 5.63-5.65 and 5.74. For more details, see Espa (2015), pp. 194-202.
} 
exceptions, that is, Article XX (b) and Article XX (g) GATT, ${ }^{142}$ could in principle cover RE subsidies but neither of them would really be suited to justify them in case of ASCM-inconsistency. This holds true for Article XX (g) GATT, inasmuch as (i) the "related to" test does not require that the environmental effectiveness of a measure be balanced with its trade-distortive effects and (ii) the "even-handed" standard is not easily applicable to RE subsidies, be it FIT schemes or other public incentives. ${ }^{143}$ Similarly, for Article XX (b) GATT, the necessity test therein focuses on the traderestrictive impact of a challenged measure rather than the much more comprehensive notion of trade-distortion espoused in the ASCM. ${ }^{144}$ More fundamentally, even if a newly drafted general exception clause were to solve these limitations along the lines of the EU example, the fact remains that this is an avenue that could only shelter multilaterally challenged RE subsidies, while proving totally ineffective in affording protection to those RE subsidies that are instead counteracted via unilaterally imposed CVDs. However, as previously noted, unilateral trade remedy actions are on the rise ${ }^{145}$ and this is a direct consequence of the specificity of WTO subsidy law compared to EU State aid law, limiting further the scope for transposing the latter regulatory model to the former.

\section{Conclusions}

Our comparative analysis has shown that the EU and WTO regulatory approaches to RE subsidies present some similarities but also important differences in terms of both negative and positive integration. Three conclusions may, in particular, be drawn from this analysis that can be of interest in light of the overarching theme of this special issue.

First, positive integration requires the establishment of common rules and institutions as much as negative integration does. This is well illustrated by the EU regime, where both dimensions are present, as well as by the WTO regime which only follows the logic of negative integration.

\footnotetext{
${ }^{142}$ As it is known, GATT Article $X X(b)$ and Article $X X(g)$ respectively justify measures "necessary to protect human, animal and plant life or health" and "related to the conservation of exhaustible natural resources". Pursuant to the introductory paragraph of Article XX GATT, any such measure cannot be "applied in a manner which would constitute a means of arbitrary or unjustifiable discrimination between countries where the same conditions prevail, or a disguised restriction on international trade".

${ }^{143}$ See Marín Durán (2018), pp. 161-162, and Espa and Marín Durán (2018), pp. 645-646.

${ }^{144}$ Marín Durán (2018), pp 161-162, and Espa and Marín Durán (2018), p. 646.

${ }^{145}$ See above, Section 2.
} 
Second, negative and positive integration may be seen as two sides of the same coin: the stronger the former, the greater the need for the latter. In this regard, our analysis has shown that while both the EU and WTO regimes share some basic tenets of negative integration, they are fundamentally different in both substantive and institutional terms. On the one hand, the latter is much less constraining on government support because, unlike under EU State aid law, the ASCM does not lay down a general prohibition on subsidies (i.e. a prohibition which takes effect irrespective of the need to prove actual trade-distortive effects), nor does it count on anything equivalent to the European Commission's centralized supervisory and enforcement powers. This means that the need for a mechanism aimed at balancing the negative (trade-distortive) and positive (climate-friendly) effects of RE subsidies is not as strong or obvious within the WTO context as it is under EU State aid law. On the other hand, the less centralized control system of the WTO (i.e. permitting also unilateral trade remedy action against trade-distortive RE subsidies) creates distinct challenges on which the EU regulatory model cannot offer much guidance.

A third and final point is that the fundamental political and the institutional differences exhibited by the EU and WTO regimes render a comparison of their regulatory approaches to $\mathrm{RE}$ subsidies more useful in theory than in practice. Based on our analysis of the actual legal risks that RE subsidies face under current ASCM rules, we have argued that the only meaningful balancing mechanism would consist of introducing a full exemption that would shield certain "good" RE subsidies from ASCM-based challenges on both multilateral and unilateral fronts, along the lines of the EU GBE Regulation. Yet, as shown by the EU's experience, positively defining sufficiently detailed terms and conditions under which RE subsidies are deemed permissible is a highly complex regulatory endeavour, which in the case of the EU has turned out to be possible mainly thanks to the extensive and exclusive powers of the European Commission. It is thus hard to see how this positive integration dimension can be replicated in the WTO, given the absence of a supranational body with equivalent decision-making and overseeing functions that could bridge current divisions among WTO members on what may and may not be "good" RE subsidies. 


\section{References}

Asmelash H B (2015) Energy subsidies and WTO dispute settlement: only renewable energy subsidies are challenged. Journal of International Economic Law 18: 1-25

Bacon K (2013) European Union law of State aid. Oxford University Press, Oxford

Bigdeli S Z (2011) Resurrecting the dead? the expired actionable subsidies and the lingering question of "green space". Manchester Journal of International Economic Law 8: 2-37

Callaerts R (2015) State aid for the production of electricity from renewable energy sources. European Energy and Environmental Law Review 17: 17-26

Charnovitz S and Fischer C (2015) Canada - Renewable Energy: implications for WTO on green and not-so-green subsidies. World Trade Review 14: 177-210

Chatzivasileiadis S and Ernst D (2017) The state of play in cross-border electricity trade and the challenges towards a global electricity market environment. In Espa I and Cottier $\mathrm{T}$ (eds), International Trade in Sustainable Electricity: Regulatory Challenges in International Economic Law. Cambridge University Press, pp 21-45

Condon B J (2017) Disciplining clean energy subsidies to speed the transition to a low-carbon economy. Journal of World Trade 51: 675-690

Cosbey A and Mavroidis P C (2014) A turquoise mess: green subsidies, blue industrial policy and renewable energy - the case for re-drafting the subsidies agreement of the WTO. Journal of International Economic Law 17: 11-47

De Bièvre D, Espa I and Poletti A (2017) No iceberg in sight: on the absence of potential and actual WTO disputes against fossil fuel subsidies. International Environmental Agreements: Politics, Law and Economics 17: 411-415

Ehlermann C-D and Goyette M (2006) The interface between EU State aid control and the WTO disciplines on subsidies. European State Aid Law Quarterly 5: 695-718

Espa I (2015) Export restrictions on critical minerals and metals: testing the adequacy of WTO disciplines. Cambridge University Press, Cambridge

Espa I (2017a) Addressing green energy subsidies in the WTO in the era of climate change: the challenges ahead. Diritto del Commercio Internazionale 31: 1-16

Espa I (2017b) Promoting renewables in the energy union: current strategies and the challenges ahead. European Investment Law and Arbitration Review 2: 225-244

Espa I and Marín Durán G (2018), Renewable Energy Subsidies and WTO Subsidy Law - Time to Rethink the Case for Reform Beyond Canada - Renewable Energy/FIT Program. Journal of International Economic Law 21: 621-653 
Flett J, Jessen A. C. and Talaber-Ritz K (2008) The relationship between WTO subsidies law and EC State aid law. In: Dauses (ed) EC State aid law. Kluwer Law International

Hestermeyer H P and Nielsen L (2014) The legality of local content measures under WTO law. Journal of World Trade 48: 553-591

Horlick G and Clarke P A (2017). Rethinking subsidy disciplines for the future. E15 Task Force on Rethinking International Disciplines-Policy Options Paper. E15Initiative. Journal of International Economic Law 20: 673-703

Kampel K (2017). Options for Disciplining the Use of Trade Remedies in Clean Energy Technologies. Geneva: International Centre for Trade and Sustainable Development

Marín Durán G (2018) Sheltering government support to "green" electricity: the European Union and the World Trade Organization. International and Comparative Law Quarterly 67: 129-165

Meyer T (2018) How selective enforcement of trade laws chills innovation. Forthcoming

Ramirez Carmona F (2016) The feed-in tariffs entanglement: a comparative study of the analytical approaches followed by the EU and WTO judiciary bodies regarding renewable energy subsidies. Legal Issues of Economic Integration 43: 201-228

Rubini L (2012) Ain't wasting time no more: subsidies for renewable energy, the SCM agreement, policy space and law reform. Journal of International Economic Law 15: $527-579$

Rubini L (2015) The wide and the narrow gate: benchmarking in the SCM agreement after the Canada - Renewable Energy/FIT ruling. World Trade Review 14: 211-237

Shadikhodjaev S (2015) renewable energy and government support: time to green the SCM agreement? World Trade Review 14: 479-506

Steenblik R and Simon J (2010). A new template for notifying subsidies to the WTO. Geneva: International Institute for Sustainable Development

van den Bossche P and Zdouc W (2017) The Law and Policy of the World Trade Organization. Cambridge University Press, Cambridge

Vermulst $E$ and Meng $M$ (2017) Dumping and subsidy issues in the renewable energy sector. In Espa I and Cottier T (eds), International Trade in Sustainable Electricity: Regulatory Challenges in International Economic Law. Cambridge University Press, pp 336-355 